\title{
Being-Country in Urban Places: Naming the World Through Australian Aboriginal Pedagogies
}

\author{
Margaret Somerville, Sarah Powell, and Narelle Trist
}

\begin{abstract}
Margaret Somerville is a professor of education at Western Sydney University. She is interested in alternative and creative approaches to research and writing, with a focus on relationship to place and planetary well-being. She has a long history of research collaboration with Australian Aboriginal people and communities and has published 4 books, 11 book chapters, 7 journal articles, 3 research reports, and 5 art exhibitions from this work, in collaboration with Aboriginal participants. Her most recent research, Naming the World, draws on posthuman and new materialist theories and Indigenous eco-philosophical approaches in collaboration with very young children and their extraordinary capacities in world naming. Email: Margaret.Somerville@westernsydney.edu.au
\end{abstract}

Sarah Powell is lecturer in creative arts (music) at Macquarie University. Prior to joining Macquarie, Sarah worked in the School of Education at Western Sydney University, focusing on arts in education and literacy in early years learning. Sarah collaborated with Margaret Somerville and Narelle Trist in Naming the World through her interest in music. Narelle's approach to working with children, her emergent Indigenous pedagogies, intersected effectively with Sarah's embodied approach to music and movement, where stories and song and listening are a physically enacted literacy of experience. Sarah is interested in the potential of music to bring diverse cultural understandings together through the embodied nature of music and its integral part in all aspects of our lives.

Email: sarah.powell@mq.edu.au

Narelle Trist is an Aboriginal education officer at Noumea Public School in Shalvey, Western Sydney. She comes from Brewarrina in Murrawarri Country. Her mother is a Murrawarri woman and her father is a Dharug descendant. Her work at Noumea Public School involves providing Aboriginal input across all ages and year levels of the school and linking with the local Aboriginal parents and communities. She specializes in developing resources consisting of found objects for children's learning and creative engagement. Through these resources, Narelle supports learning across all subject areas. Her resource room provides a place of excitement and creative learning where children can make new things from discarded objects (e.g., jacaranda pods, bark, sticks, leaves) to improve learning outcomes. Email: Narelle.Trist@det.nsw.edu.au

This paper explores the pedagogies of a Murrawarri/Dharug co-researcher enacted during three activities: becoming animal; welcome dance; and message sticks. We thinkwith Trist and consider the possibilities of beingCountry in urban places. The research draws on data collected as part of Naming the World, an international project informed by posthuman and new materialist theorizing and Indigenous understandings of humans as fully intertwined with the world. We grapple with the intersection of posthuman and new materialist perspectives alongside Indigenous onto-epistemologies in early childhood education settings.

Key words: being-Country; Indigenous; posthuman; onto-epistemology; new materialism
In this paper we explore the pedagogies enacted by a Murrawarri/Dharug teacher and co-researcher, Narelle Trist, through activities she brought to the children at Western Preschool, located in a significantly disadvantaged area of western Sydney. The examples chosen for this paper include learning and performing Indigenous animal names, physically enacting an animal story, learning a traditional welcome dance, and creating personal message sticks. As Narelle engaged with children, she enacted her Indigenous ways of knowing, being, and doing, her onto-epistemology, and her full and total entanglement with her worlds. The international research project Naming the World: Enhancing Literacy and Sustainability Learning in the Early Years forms the backdrop for our discussion of Narelle's pedagogies and our exploration of being-Country in urban places. We collaboratively explore the enactment of Narelle's distinctive Australian Aboriginal approach within the posthuman and new materialist framings of the project as a whole. 
We begin by considering the literature that helps frame our thinking around the intersection of Indigenous and Western onto-epistemologies in early years learning. We contemplate the significance of land, settler colonial impact, and language/naming. We describe our research project, Naming the World, to contextualize the discussion, and we introduce Narelle-in-Country through her depiction of herself, using a written and graphic language map. We present a number of data examples, which form the basis of our discussion of Narelle's activities with the children at Western Preschool.

\section{Literature}

In Western systems of early childhood education, there continues to be an ontological and epistemological problem of separating culture (as language) from nature (as world). A large and developing body of work in early childhood research has grappled with new materialist concepts, such as intra-action and entanglement (Barad, 2007), and has sought to apply these concepts in settler colonial contexts (Lenz Taguchi, 2010; Pacini-Ketchabaw, 2013; Pacini-Ketchabaw, di Tomasso, \& Nxumalo, 2014; Somerville, 2018; Taylor \& Giugni, 2012). Theorizing within these framings challenges the powerful nature-culture binaries that are familiar to Western humanist philosophies, which separate humans from the rest of the planet. In contrast, these framings align with Indigenous onto-epistemologies, which have always understood humans to be inextricably intertwined with the world and its becoming (Somerville, 2013). Many early childhood education researchers have recognized the possibility of bringing these fundamentally different philosophies into conversation.

The complexities characteristic of Indigenous onto-epistemologies and the difficulties that Western systems of knowledge have with integrating or accepting these in settler colonial contexts is the subject of much research literature. Indigenous onto-epistemologies across the world acknowledge that all things are connected and impact each other. They see the relationships between all things, human, nonhuman, and more-than-human, as integral to being, and it is these relationships that foster knowledge and understanding (Ritchie, 2013). Somerville and Hickey (2017) discuss the failure of the Australian curriculum to fully engage with Australian Aboriginal ways of being and knowing. They use "thinking through Country" to grapple with the vastly different cultures and philosophies that continue to disconnect Western, settler colonial systems from indigenous Australian Aboriginal systems. Thinking through Country (Marshall, 2007; Somerville, 2013, 2018) was developed by Chrissiejoy Marshall as part of her doctoral study and journey. As a methodology, it "enacts ongoing relations with natural elements and forces, and is manifest in narratives and cultural practices" (Cole \& Somerville, 2017, p. 73), having emerged as a result of Marshall challenging "conventional discourse" (p. 74) and developing her own Indigenous onto-epistemology. Like posthuman and new materialist conceptualizations of being, including the notion of a flat ontology, thinking through Country perceives and experiences life as interconnected, equal, and nonhierarchical, not as disconnected entities with greater or lesser value.

Karen Barad's (2007) notion of intra-action aligns with Indigenous onto-epistemologies in that it describes the internal relatedness of all things, where all things have agency (Martin, 2017) and impact each other. In a discussion about indigenous research methods, Karen Martin (2017) identifies the separation that occurs in Western representational thinking that does not account for "everyday living" (p. 1393). In contrast, an Indigenous worldview is based on "the premise of a 'real' relationship people have to an inseparable cultural ideology that is premised on Country" (p. 1396). Even knowledge has agency and is fluid, and for Indigenous people, the way knowledge is acquired and how it is shared is as important as the knowledge itself, and it is completely entangled with the everydayness of being.

The understandings embodied in education in settler colonial societies are seen as operating against Indigenous 
ways of being in and knowing the world, to the point of the erasure of an Indigenous presence (Martin, 2017; Ritchie, 2013, 2014, 2016). A study conducted in Aotearoa (New Zealand) by Jenny Ritchie (2013) was based on Bruno Latour's (2004) notion of matters of concern. One of these matters was that Indigenous onto-epistemologies were invisible in early childhood educational settings. In this colonial context, Indigenous peoples and the environment are constantly overlooked. The Indigenous onto-epistemology in this Maori context sees humans as inseparable from and reciprocally dependent on the world, both locally and globally. Ritchie discusses the urgent need to recognize and validate Indigenous ways of being, knowing, and doing (p. 397) in order to address the destruction caused by Western dualist systems of thought about the environment and human "detachment from the morethan-human world" (p. 397). Similarly, Michelle Salazar Pérez and Cinthya Saavedra (2017) challenge the Global South/North distinction that exists in America in the early childhood education field, arguing that Global South onto-epistemologies have been disregarded. They advocate "centering the lived ways of knowing and being" (p. 2) of marginalized children, and call for the recognition of diverse onto-epistemologies.

Concepts of Land and Country embody profound ontological and epistemological differences to the often-invisible underpinnings of environmental education (Tuck, McKenzie, \& McCoy, 2014). Veronica Pacini-Ketchabaw (2013) asks, "What might happen when we pay attention to how Indigenous peoples and their ontologies and epistemologies are erased from child care forest pedagogies?" (p. 356). She draws on Anna Tsing's (2005) concept of friction to explore the divergent social relationships of the modern world. Like many, Pacini-Ketchabaw understands that colonial practices have silenced Indigenous naming practices (p. 359). She describes an early childhood game that explores folk, scientific, and children's naming practices in relation to Chickadee Woods. The paper concludes with the challenge to pay close attention to the lively collaborations between "Indigenous peoples, the land, the forest, settlers, other pedagogies, animals, families, and so on" (p. 361). Eve Tuck and her colleagues McKenzie and McCoy (2014) discuss the significance of naming and language in Indigenous education, particularly in relation to land. "Naming" in learning is recognized as the "site at which issues with references between Western and Indigenous epistemologies unfold" (Bang et al., 2014, p. 47).

Land is an integral feature of Indigenous onto-epistemology. Ritchie (2016) draws on "alternative conceptualizations, drawing on post-humanist and Indigenous theorizing" (p. 78). Relationship with land is an integral part of Maori cosmology, which "situates humans, trees, birds and other creatures as fellow descendants of Sky Father (Ranginui) and Mother Earth (Papatūā nuku)" (p. 79). Again, this intersects with the concept of intra-action, where all things are integrally connected and equally part of the world's being and becoming.

Land is also significant for Arrente children. Affrica Taylor (2013) asks what we might learn about children's postcolonial nature-culture relations from Arrente caterpillar children living in the Aboriginal fringe camps around Alice Springs (p. 366). Here, land is related to the traditional caterpillar dreaming story and to "sacred rock paintings in the cliffs around the waterhole" (p. 370). This is an entangled story of Aboriginal and colonial settler that has transformed the traditional storytelling of Mparntwe Country. Enacting local knowledges and ways of being and doing is taken up by Carol Rowan (2015), who explores the relationship between Inuit peoples and their "land, water, ice, and snow" (p. 199). She talks about the "situated and specifically Inuit nunangat pedagogy" (p. 198) integral to early childhood education in the Canadian arctic. Nunangat is the Inuit word or concept for land, encompassing land, water, and ice and also "weather, waterways, animals" (p. 203). Rowan notes that settler colonial systems have severely jeopardized Inuit relations with land because of ongoing Euro-Western development (p. 202). She describes the pedagogy of an Elder, Elisapi, through the carving of snow. The children watch this Elder, learn from her, and then do what she has shown them. This is nunangat pedagogy that understands and acknowledges the agency of the snow. The snow 
exerts its agency on the child within their interaction, as well as vice versa. The snow is teaching the child about its carveability-it is affording certain kinds of carvings to emerge. It is a co-production involving snow, tool, and child. (p. 206)

In another project, Somerville and Hickey (2017) analyze children's multimodal images and texts, where children planted native groundcover species in the school grounds (p. 1427). Land and Country are understood here in terms of remnant patches of the ecological community of the Cumberland Plains, which were cleared for agricultural use and urban development. These areas are now considered endangered (p. 1429). A settler colonial critique of this history acknowledges the impact of colonization on the Cumberland Plains. A significant part of this project was teaching Aboriginal English and producing a book, which begins with the translation of a child's story into Aboriginal English and displays artworks and Aboriginal symbols. The pedagogies involved were powerful. They "underlie the extraordinary and transformative potential realised when indigenous approaches and environmental education are genuinely integrated" (p. 1438).

The data examples we use demonstrate how Narelle Trist's onto-epistemology translates to her pedagogy and exemplifies total entanglement of her land and Country, language, colonization, and pedagogy.

\section{The project: Naming the World}

Naming the World: Enhancing Literacy and Sustainability in Early Years Learning (2016-2019) is an international research project investigating the ways young children name their worlds. It responds to literacy and sustainability outcomes expressed in the Australian Early Years Learning Framework (EYLF), which broadly understands literacy as "the capacity, confidence and disposition to use language in all its forms" (p. 38) and identifies "the interdependence between people, plants, animals and the land" (p.29). This research sought to "think these together" and explore the way children use "languages" to make sense of their world(s). The notion of literacy+sustainability was formed and various categories were created to help make sense of data (Somerville \& Powell, 2017). We use three of these categories to discuss Trist's pedagogical examples: becoming animal; drumming, singing, dancing, rhythm; and artefacts and imaginative play.

Seven early learning sites from Australia and Finland were involved in the project. In Australia there were three sites in New South Wales (NSW), two in Victoria, and one in Queensland. A kindergarten in Oulu, Finland, was the seventh site. The children involved were aged 0-6 years.

The research was structured in two main phases. We describe the first phase as the "deep hanging out" phase (Geertz, 1998; Walmsley, 2018; Wogan, 2004), which involved 6-12 months of being with children in their education setting (e.g., long daycare, preschool), observing them at play, outside in the playground, and inside in their classroom. We would be guided by the children and only enter a game or conversation when invited or approached. Our deep hanging out reflects Donna Haraway's (2015) notion of curious practice, where everything is interesting, where we expect to be surprised, and where research starts from a point of openness, without preconceived notions of what should be discovered.

The second phase saw the educators develop a project to implement with the children. For some, this meant devising music activities to add to a day or embedding Indigenous language in literacy activities, such as word recognition and greetings. For others, it involved constructing a riverbed in adjacent bush land, or connecting with children in Finland through the exchange of stories, drawings, and language. For Narelle, it meant engaging children in traditional Aboriginal dance, language, and storytelling.

This paper focuses on one NSW site, Western Preschool, which is located in Sydney's west, the fastest growing 
urban area in Australia. It is the destination of choice for newly arrived migrants and refugees, with over 100 languages represented. It has the highest concentration of Aboriginal people, $30 \%$ of whom come from elsewhere in Australia. Western Preschool stands on a street corner in a high-poverty suburb and is secured by high, barred, metal fencing. Across the road is a small shopping complex, main road, and suburban streets. The preschool provides for children from a range of ethnicities, including Aboriginal children.

The researchers, Margaret Somerville and Sarah Powell, visited the preschool on a regular basis as part of the deep hanging out phase. We observed children, interacted with them, and got to know the educators. Narelle Trist joined the research project in its second phase (the pedagogical phase), but was known to many of the staff because she had contributed there before. Narelle came to the preschool on a regular basis and provided pedagogical experiences for the children. She enthusiastically embraced the research, taking leadership of her own pedagogical activities, and was happy to be the focus of our video recording. Her participation in this paper has been to generate the pedagogical ideas behind these activities as her intellectual property and to welcome the opportunity to contribute to this publication through our presentation and analysis of a small number of videos and fieldnotes. This paper highlights three examples, which we identify as becoming animal, welcome dance, and message sticks. Narelle enacted her distinctive Australian Aboriginal approach through these activities, which were situated within the posthuman and new materialist framings of the project as a whole and exemplify the intersection of these framings with Indigenous onto-epistemologies.

The following segment is Narelle's representation of herself. Her identity directly relates to the enactment of her pedagogy and is distinguished by her powerful Being-Country in this urban place.

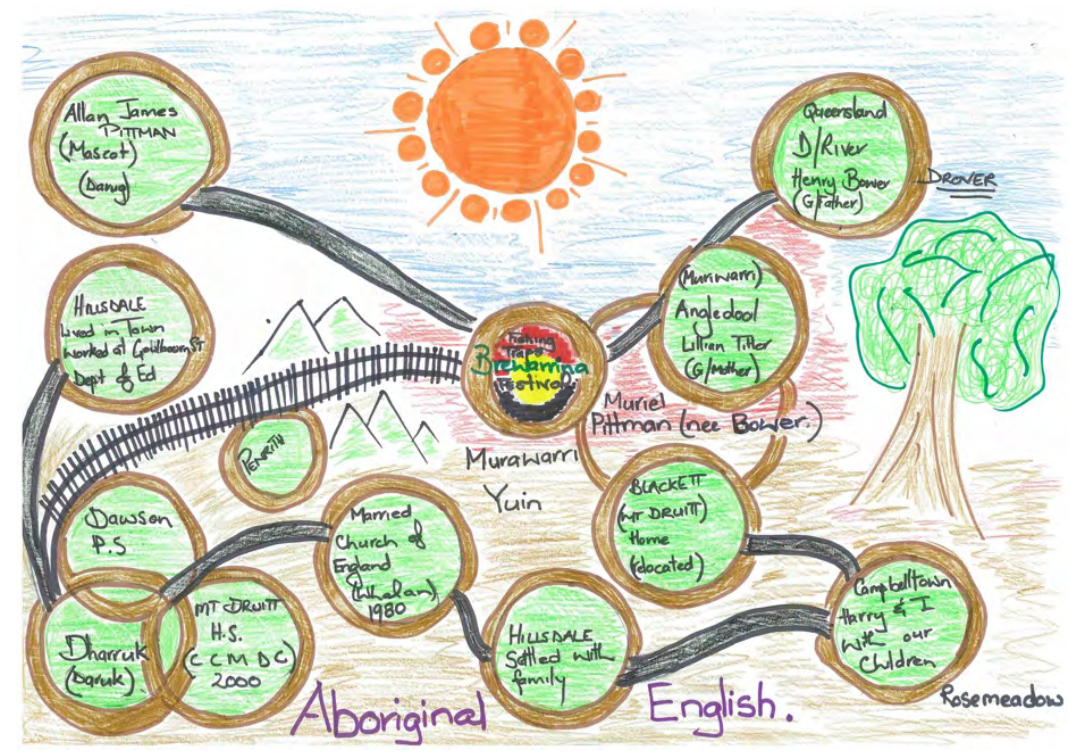

Figure 1. Narelle Trist's language map.

\section{Being-Country: Narelle Trist}

The diagram in Figure 1 was created by Narelle as part of another project (Pathways to Engagement, 2016) that sought to map the everyday language practices of students at schools in a highly disadvantaged area of western Sydney, to develop pedagogies based on these practices, and to support English curriculum outcomes (Hickey, Trist, Bell, Lee, Somerville, \& Power, 2016). The maps were created by Aboriginal education officers (AEOs) who introduced themselves, drew a "map" of their language practices and history, and discussed what they had produced.

The maps are significant for this paper because they encapsulate an identity shaped by history,

experience, and language. The verbal narrative of Narelle's language map enhances her drawing:

Hi my name's Narelle Trist. I originate from Brewarrina in Murrawarri Country. My mother is a Murrawarri woman, my father's a Dharug descendant but my mum's father is from Queensland, born on the Diamantina River, my grandmother is from Angledool. My parents brought us down to Mount Druitt in early 1970s for better education for the future for her children. So we came down on the old steam train down from Brewarrina all the way down to Penrith which from there we caught a taxi out to Mount 
Druitt to the first five-bedroom home in Mount Druitt. From there we attended Dawson Public School; then we went to Mount Druitt High School. I was married 1980 in Mount Druitt, settled in Hillsdale then Campbelltown, but we all come back to Mount Druitt because all our family's there. The green represents life, the red represents the red dust, brown represents the earth and the green on the mountains but also the sun. We cannot grow-plant nor human being-will grow without sunlight as it holds the most important thing, vitamin D with sunlight to help you grow. (Hickey, Trist, Bell, Lee, Somerville, \& Power, 2016, pp. 13-14).

The map constructed here, in both visual and written form, is a powerful narrative that Narelle brought to her daily practice as educator and advocate, an identity that she also brought to our project, her being-Country in urban places, enacted through her pedagogy with the children at Western Preschool.

\section{Data and discussion}

In this section, we provide examples of Narelle's pedagogies with the children at Western Preschool. We have transcribed them from short iPhone video recordings and from fieldnotes, framing the activities in three categories: becoming animal; drumming, singing, dancing, rhythm; and artefacts and imaginative play.

\section{Becoming animal}

\section{Video 1: Animals}

Children are sitting on the floor. Narelle holds up a laminated picture of an Australian animal and recites each name for the children to mimic.

"Badagarung," she says, and the children repeat, "Badagarung."

"Aaaah," she says dramatically, leaning forward.

The children call out, "Snake by the creek."

"Yeees, but what does he do?" She raises one arm from the elbow with fingers bent at knuckles, mimicking a snake's upright posture. "But what does he do?" She hisses loudly. "He's called Bulada, Bulada." The children repeat it.

Another dramatic pause and then, "Aaaawh, who's this beautiful girl? Mother Emu, Muriyung, Muriyung." Again, the children repeat.

"Ooooh, who's this cuddly one?"

"Koala!" the children shout.

"Hooray, yeah, but where do they live with their family? And what does she do with her family? In a tree, a eucalyptus tree?”

"In the jungle," suggests one child.

"Not in the jungle, pretty, they live where there's a lot of bush, and see that tree? (points to picture) They climb on, that's their food (fingers poised at lips in chewing motion), 'cause they don't drink water, either" (shaking head).

"How does he drink water?" asks a child.

"He gets all the moisture out from the leaf. He gets all the moisture out from the eucalyptus leaves" (fingers to lips 
again). "I'll have to get a eucalyptus leaf and I'll bring it in for you, and I'll let you smell it and I'll let you touch it" (hand out, fingers curled, rubbing each other).

"OK, Okaaaay, aaaah (big sigh), who's this?"

"Dingu," children call out.

"Dingu," Narelle responds. "And what is he?"

"He’s a puppy," answers one child.

"No, he's a dingooooo. And what did our dingo do last week? How many dingoes have I got?" (stretches arms out open wide as if to include the whole group)

The children immediately begin howling, heads lifted, looking towards the sky, hands cupped in front of their mouths, making piercing howls. Narelle's arms move to conductor position and she begins counting, 1, 2, 3, signalling to them to howl again, which they all do simultaneously and with great pleasure and animation. It continues on and on and on.

End

Video 2: Being-becoming Animal

Narelle reads Kangaroos Hop, and with each page of the book the children become the animal: hopping kangaroos, flying birds (their arms for wings), shuffling echidnas, dancing butterflies, running lizards (with tiny steps), crawling crabs (on all fours), and jumping frogs.

Narelle pauses. "The frogs jump to the river bank wheeere ... (pauses in silence as the children respond) ... Are you sure?"

She holds up the book to show the picture. "Shhhhhh (finger to lips). The big fat crocodile is sleeping."

The children are jumping up and down in excitement.

"Are you sure?"

The children respond: "Crocodile."

Narelle says, "Crocodile, yeah, yeah" as the children continue to jump, shouting, "Crocodile!"

End

There are two main sequences in Narelle's repeated performances of becoming animal. In the first, the children learn the names of Australian native animals in both English and the local Aboriginal language, Dharug, from a series of images Narelle has created as a resource. The second sequence involves reading the book Kangaroos Hop, written by Ros Moriarty and illustrated by Aboriginal artist Balarinji. Ros Moriarty is described as "founder of Indi Kindi pre-literacy education" and is the author of the acclaimed Listening to Country, a memoir of her journey across Country and culture with the matriarchs of her husband's Aboriginal family (Moriarty, 2011). 
Kangaroos Hop involves kangaroos, birds, echidnas, butterflies, lizards, fish, crabs, goannas, frogs, and crocodiles. It introduces each animal, with its accompanying movement or action, in a cumulative fashion, so that by the end of the book, children are reciting and enacting the whole sequence of animals and performing their characteristic movements.

In these performances, land is performed through the bodies and movements that depict native animals, their actions, and their habitats. In many senses, the enactment of the animals evokes the Country of its habitat-the snake by the creek, the koala chewing leaves in its eucalyptus tree-in a quintessential settler colonial context. The children at Western Preschool enter the Country of the animals as a place of imagination; it is too dangerous and too disturbing for many of the children to leave the grounds of the preschool. They join with Narelle in experiences that directly connect them with a very different time and place, an Indigenous past of knowing, being, and doing, with an embodied real and present knowing, being, and doing.

Learning and performing Dharug animal names is also an embodied experience for these children and is central to the pedagogy in this performance. However, it is much more embodied than just language as abstract and disconnected words. The children become the animals; they feel the movement in their bodies; they howl like a dingo, smell the gum leaf with the koala. Their participation shows a "depth of sensory, embodied engagement [that] enables their response-ability within these intra-actions" (Ritchie, 2016, p. 88). In this embodied engagement, the children learn to name their worlds through their relation with Narelle's performing body, the collective bodies of children, the animals, and their habitats, and the book through which they learn to read and perform. The pictures and the book come to life in this enactment. This urban preschool room momentarily transforms into being-Country.

\section{Drumming; singing; dancing; rhythm}

Video: Welcome Dance

Seven girls are lined up, standing in a row beside Narelle, who leans forward, arms extended in front of her body, hands facing each other, ready to clap the beat.

Narelle leans into a swinging walk forward, clapping her hands and counting as she does: 1, 2, 3, 4, 5, 6, 7, 8. Her hips swing from side to side in gathered cotton skirt, arms and hands following the same movement and rhythm: clapping, counting, moving, swinging.

The girls follow her, repeating movements to the rhythm of their counting and clapping: $1,2,3,4,5,6,7,8$. On the last count, Narelle turns back to face where they have come from and continues with the same movement and rhythm: hips swinging, arms waving, hands clapping, repeating the counting: $1,2,3,4,5,6,7,8$.

The girls following Narelle turn and repeat their movement, counting and clapping, 1, 2, 3, 4, 5, 6, 7, 8. As they reach the count of 8 and arrive back at the starting point, Narelle raises her arms as high as she can reach, takes in a deep breath, and, as arms and hands reach their furthest extent, blows out all her breath with a very loud "Oyyyyyyyi" and the girls follow suit, raising their tiny arms and shouting in pleasure and release.

She does the same with the boys, but the steps are different.

End 
In these examples, land is represented by evoking the ritual of welcome, performed in traditional times when neighbouring tribal groups entered the territory or home Country of the welcoming group. With over 500 distinct Aboriginal languages defining their own ecological territory prior to settler colonial invasion, the rituals of crossing over or walking through another's Country were elaborate and essential. In traditional times, it was also customary for the visitor to call out in their own language to the spirits of Country to let them know that someone from another Country was approaching (Somerville \& Perkins, 2010).

In the context of settler colonization, the welcome ritual has been translated into the customary performance of a ritualized speech, usually given by an Elder from the Country location of a gathering. Often the speech is given in the speaker's language and some form of identification of Country is performed. In the absence of an Elder from that Country, the practice is for an Aboriginal person to perform an acknowledgement of Country to let Country know that visitors are present. According to Narelle, part of learning the welcome dance is for children to learn to respect everyone. They learn to "embrace all cultures-rainbow people-and respect everyone for all their differences, not just skin colour." This is especially important at Western Preschool because there is a large diversity of ethnic backgrounds represented. Narelle says, "Everyone needs to learn to be okay together."

In the welcome dance, the children learn to enact a welcome according to some of the traditional protocols of the traditional Indigenous performance of welcome to Country. The girls and boys learn separately. They learn the body moves differently according to each gender. Girls swing their hips and arms from side to side; boys stomp their feet in a leaning-forward action of rhythmical stomping and clapping. Tapping sticks or hand clapping is used with particular dance steps to accompany body rhythm and movement, a vital part of the performance. The children count their steps out loud, becoming the embodiment of both number and rhythm. The finale is the loud shout, a call to the spirits of the Country to let them know that the visitor has arrived. This pedagogical activity clearly expresses Narelle's Indigenous onto-epistemologies. It incorporates Indigenous rituals, known across different Aboriginal peoples, and is simultaneously a physical enactment of such a welcome ritual through the interpretation of a moment in an urban preschool. The children become-with Narelle and experience a beingCountry with her as they clap and count and stomp. Thousands of years of Indigenous being and knowing come together with Narelle and these ethnically diverse children in a moment of doing.

\section{Artefacts and imaginative play}

\section{Video 1: Message Sticks}

Narelle sits with a young boy, her face and gestures expressing an exquisite tenderness as she assists him in his identify-forming message stick making.

They are sitting at the table with remnants of other children's makings, three black plastic ice cream containers, one with white glue and two paintbrushes; a second with a variety of brightly coloured paper and a white cup; and a third with sand. Scattered across the table are white and pink pipe cleaners, two white cups, and sand.

Narelle leans in towards the boy whose hands are poised over a green message stick that she holds out for him while he sprinkles stars onto some glue. His body looks down shyly. Narelle's face, smiling and so attentive, looks towards him as she gently presses the stars into the glue.

She turns the stick and says, "A little bit more there? What else would you like other than stars? We got eyes (picking up white cup and placing it in front of the boy who looks down into it). And where would you like to put two eyes if you got eyes? Down here? Which side but?" (holding stick up, turns it around). 
The boy tilts his head to one side, contemplating the message stick. "Ummm," shyly pointing, he looks down, hesitating.

"Well, you get your eyes out, Aunty Relle put them on." She takes a paintbrush and dabs paint gently onto the message stick while the boy gets eyes out of the white cup. Eyes are glued on.

End

Video 2: Message Stick-Story 1

Five children sit at the table with Narelle. She holds her message stick up to show the children. Her other arm stretches out wide.

She says, "She [emu] is letting everybody know that she has laid her eggs, and that old man emu is sitting on them (nods approvingly towards message stick and children). But also (pointing to the top of the message stick), my stars, they not only remind me of my Country. They remind me of my life, because I work with little bright stars (hand on heart, fingers spread wide). My children are my little bright stars" (smiling and nodding at a child).

She holds the stick up again and points. "See this? (pipe cleaners wound around stick) That's like a nice brown, 'cause my Country is a sunburnt country. See the sand? (pointing again at message stick, the bottom this time) That represents Western Preschool with my little superstars (pointing to the stars again and nodding to the children). OK?"

End

Video 3: Message Stick-Story 2

Narelle has the message sticks that the children made last week. She tells them her story, pointing at the patterns and decorations on her message stick as she speaks.

Narelle then invites each child to tell her or his story. Sixteen children take turns to tell their story, huddled close to Narelle, her arm protectively enveloping them. She holds their hand in hers with the message stick safely in both their grasps. The children say things like "Pink is my favourite colour"; "I need stars"; "I love stars"; "Stars are from my tree"; "The eyes are my house watching me"; "The green is my tree"; "Gold is my mummy and daddy"; "The eyes are watching my mummy when she is sick"; "The stars are Mummy, Poppy, and Grandma looking after me."

End

For Australian Aboriginals, traditional times were composed of everything that made up Country. This included elements of rock, stone, sand, soil, water, air, and fire; the weather, wind, storms, and the seasons; the contours of the land, hills, valleys, creeks, rivers, and waterways; all living creatures, reptiles, mammals, birds, insects, spiders, fish, amphibians, and so on, ad infinitum. Everything in its totality is Country, including its humans. Country was also a specific place, as well as the relationship between all places. Red, yellow, and white ochre were used with humans for body and ground designs in ceremony, and also to transmit messages on sticks from one human clan to another. Sticks and bark were the most accessible mobile forms of inscription and communication. 
The message stick activity by Narelle denotes land as a powerful expression of shared identity in Country. The message stick was also a sign of permission to enter the Country of the other. For Narelle, land plays an integral role in the communication of her and the children's identity, as her language map shows. At Western Preschool, the activity takes place in a highly urbanized settler colonial context. The message sticks are made from manufactured timber rods, or dowel, and the "message" is constructed using an assortment of readily available materials, including pipe cleaners, scraps of assorted shiny paper, glitter stars, tiny plastic eyes, stickers, and sand. The materials are organized into a number of empty plastic ice cream containers in the middle of a preschool table, set up with four chairs for selected children to take their turns. The children choose how to decorate their message sticks and Narelle helps them by applying glue. She works with one child at a time, with each time being a moment of intense identity formation and sharing.

Each time Narelle holds up her own message stick, she tells her story. The stick closely resembles her language map and is a hybrid mix of traditional symbols and knowledges. Narelle's is a contemporary urban identity at Western Preschool, a being-Country in urban places. The first time Narelle begins her story it starts with the Emu, the traditional symbol for Murrawarri Country in the desert country of far western New South Wales. The red sand desert country is "a sunburnt country" where the temperatures rise up to 50 degrees in summer. The stars are so bright in this country, far from city lights, and the stars on Narelle's message stick represent her Murrawarri Country, as well as the children, her "little bright stars." On another occasion, the children are invited to tell their identity story when they return to their completed and dried message sticks. Theirs are messages of personal identity, which largely involve family who look after them. When Narelle tells her story on a different occasion, she is the sunburnt country, and the matchsticks represent the staff and the fence around the preschool that keeps the children safe. Her whole story is an amalgam of being-Country, both in times gone by and now in contemporary western Sydney.

\section{(In)Conclusion}

Examining Narelle Trist's pedagogies has opened up new possibilities for bridging the gap between Indigenous onto-epistemologies and Western systems of thought. In doing so, we have experienced the possibilities offered by the intersection of posthuman and new materialist theorizing with Indigenous onto-epistemologies. These understandings have been developed through our collaboration and have contributed significantly to Naming the World. In this work, we have seen the entanglement of peoples, ideologies, philosophies, lived experience, objects, and things, and we have seen the way this entanglement can shape pedagogy and learning. We have seen the enmeshing of Indigenous ways of knowing, being, and doing with the intra-active embodiment of land, beingCountry, and the settler colonial narrative. We have experienced the unique pedagogy of Narelle Trist, through which she enacts being-Country in this urban place. The examples we have presented portray Narelle and the children of Western Preschool "becoming animal" as they perform animal names in the Dharug language, connect these words with animal pictures, perform animal sounds, move like animals, and enact an animal story together. Through the message stick activities, we are drawn into Narelle's land and Country as she tells her story and as this is translated to the children telling their stories. Finally, we witness the full entanglement of land, Country, and settler colonial influence as Narelle teaches and performs a welcome dance with the children: an amalgamation of bodies, stories, and ritual, past and present realities, and the musical, rhythmic exchange between Narelle and the children; a new interpretation of "Welcome to Country."

We have a new vision of this work of being-Country in urban places whereby being-Country with Narelle becomes a body literacy, a memory or DNA literacy that permeates all of us from her very Being. Whether it be reading, dancing, making, hopping like a kangaroo, shuffling like an echidna, flying like a bird, howling like a dingo, or just 
sitting with the children, we become-Country in this contemporary hybrid urban place.

\section{Conclusion by Narelle Trist}

With this paper it was a privilege to work with yourself first, and with Sarah, who was very warm, and if I needed any assistance she was there, no problems. At the end of the day I feel privileged because I work with children and can see those little children coming from preschool to my school and to me it's worth all the money in the world. I get to see children come through my gate happy and to leave happy from my learning grounds. I love it. I love my community and the little preschool learning grounds because it's so child friendly. I can be a child with them and let my imagination go with the children. I am a strong believer if you read stories you have to play the part. If that means carrying on like a child, being a big kid, well, who cares? It means that you're having fun. It was a privilege to have so much fun with all the children, yourself, and Sarah Powell. The staff there always welcome any kind of learning 'cause at the end of the day all our children are colourful little rainbows and they learn in so many different ways through so many little cultures coming together. It's a privilege because we're all one when we're together. They're my children and I have to care for them and my own learning grounds. (Narelle Trist speaking with Margaret Somerville, 29 September 2018). 


\section{References}

Bang, M., Curley, L., Kessel, A., Marin, A., Suzukovich, E. III, \& Strack, G. (2014). Muskrat theories, tobacco in the streets, and living Chicago as Indigenous Land. Environmental Education Research, 20(1), 37-55. https://doi-org.ezproxy.uws.edu. au/10.1080/13504622.2013.865113

Barad, K. (2007). Meeting the universe halfway: Quantum physics and the entanglement of matter and meaning. Durham, NC: Duke University Press.

Cole, D. R., \& Somerville, M. (2017). Thinking school curriculum through Country with Deleuze and Whitehead: A process-based synthesis. In C. Naughton, G. Biesta, \& D. R. Cole (Eds.), Art, artists, and pedagogy: Philosophy and the arts in education (pp. 71-82). New York, NY: Routledge.

Geertz, C. (1998). Deep hanging out. The New York Review of Books, 45(16), 69.

Haraway, D. (2015). A curious practice. Angelaki, 20(2), 5-14. https://doi.org/10.1080/0969725X.2015.1039817

Hickey, S., Trist, N., Bell, D., \& Lee, T., with Somerville, M., \& Power, K. (2016). Pathways to engagement: Aboriginal education officers in their own words. Report produced for the New South Wales Department of Education. Retrieved from https://www.westernsydney. edu.au/cer/research/research_reports

Latour, B. (2004). Why has critique run out of steam? From matters of fact to matters of concern. Critical Inquiry, 30(2), 225-248. https:// doi.org/10.1086/421123

Lenz Taguchi, H. (2010). Going beyond the theory/practice divide in early childhood education: Introducing an intra-active pedagogy. London, UK: Routledge, Taylor \& Francis Group.

Marshall, C. J. (2007). Thinking through Country (Immiboagurramilbun) [DVD] (rev. ed.). Armidale, Australia: University of New England.

Martin, B. (2017). Methodology is content: Indigenous approaches to research and knowledge. Educational Philosophy and Theory, 49(14), 1392-1400. https://doi.org/10.1080/00131857.2017.1298034

Moriarty, R. (2011). Listening to country: A journey to the heart of what it means to belong. Crow's Nest, Australia: Allen \& Unwin.

Pacini-Ketchabaw, V. (2013). Frictions in forest pedagogies: common worlds in settler colonial spaces. Global Studies of Childhood, 3(4), 355-365. http://dx.doi.org/10.2304/gsch.2013.3.4.355

Pacini-Ketchabaw, V., di Tomasso, L., \& Nxumalo, F. (2014). Bear-child stories in late liberal colonialist spaces of childhood. Canadian Children, 39(1), 25-53. https://doi.org/10.18357/jcs.v39i1.15244

Pérez, M. S., \& Saavedra, C. M. (2017). A call for onto-epistemological diversity in early childhood education and care: Centering global south conceptualizations of childhood/s. Review of Research in Education, 41(1), 1-29. https://doi.org/10.3102\%2F0091732X16688621

Ritchie, J. (2013). Indigenous onto-epistemologies and pedagogies of care and affect in Aotearoa. Global Studies of Childhood, 3(4), 395-406. https://doi.org/10.2304\%2Fgsch.2013.3.4.395

Ritchie, J. (2014). Counter-colonial research methodologies drawing upon postcolonial critique and Indigenous onto-epistemologies. Paper presented at 10th Annual Congress of Qualitative Inquiry, University of Illinois at Urbana-Champaign, May 21-24.

Ritchie, J. (2016). Qualities for early childhood care and education in an age of increasing superdiversity and decreasing biodiversity. Contemporary Issues in Early Childhood, 17(1), 78-91. http://dx.doi.org/10.1177/1463949115627905

Rowan, M. C. (2015). Thinking with land, water, ice and snow: A proposal for Inuit Nunangat pedagogy in the Canadian Arctic. In V. Pacini-Ketchabaw \& A. Taylor (Eds.), Unsettling the colonial places and spaces of early childhood education (pp. 198-218). New York, NY: Routledge.

Somerville, M. (2013). Water in a dry land: Place-learning through art and story. New York, NY: Routledge.

Somerville, M. (2018). Posthuman theory and practice in early years learning. In A. Cutter-Mackenzie, K. Malone, \& E. Barrett Hacking 
(Eds.), Research handbook on childhoodnature: Assemblages of childhood and nature research (pp. 1-25). Melbourne, Australia: Springer.

Somerville, M., \& Hickey, S. (2017). Between Indigenous and non-Indigenous: Urban/nature/child pedagogies. Environmental Education Research, 2(10), 1427-1439. https://doi-org.ezproxy.uws.edu.au/10.1080/13504622.2017.1325451

Somerville, M., \& Perkins, T. (2010). Singing the coast: Place and identity in Australia. Canberra, Australia: Aboriginal Studies Press.

Somerville, M., \& Powell, S. (2017). Categories of analysis: Deep hanging out with children, July 2016-June 2017. Presentation to staff of UWSELL Penrith, June 2017.

Taylor, A. (2013). Caterpillar childhoods. Engaging with the otherwise worlds of Central Australian Aboriginal children. Global Studies of Childhood, 3(4), 366-379. https://doi.org/10.2304\%2Fgsch.2013.3.4.366

Taylor, A., \& Giugni, M. (2012). Common worlds: Reconceptualising inclusion in early childhood communities. Contemporary Issues in Early Childhood, 13(2), 108-120. https://doi.org/10.2304\%2Fciec.2012.13.2.108

Tsing, A. (2005). Friction: An ethnography of global connection. Princeton, NJ: Princeton University Press.

Tuck, E., McKenzie, M., \& McCoy, K. (2014). Land education: Indigenous, post-colonial, and decolonizing perspectives on place and environmental education research [Editorial]. Environmental Education Research, 20(1), 1-23. https://doi.org/10.1080/13504 622.2013 .877708

Walmsley, B. (2018). Deep hanging out in the arts: An anthropological approach to capturing cultural value. International Journal of Cultural Policy, 24(2), 272-291. https://doi.org/10.1080/10286632.2016.1153081

Wogan, P. (2004). Deep hanging out: Reflections on fieldwork and multisited Andean ethnography. Identities, 11(1), 129-139. https://doi. org/10.1080/725289021 